University of Nebraska - Lincoln

DigitalCommons@University of Nebraska - Lincoln

\title{
Inoculation of coffee plants with the fungal entomopathogen Beauveria bassiana (Ascomycota: Hypocreales)
}

\author{
Francisco Posada \\ United States Department of Agriculture \\ M. Catherine Aime \\ United States Department of Agriculture \\ Stephen W. Peterson \\ United States Department of Agriculture \\ Stephen A. Rehner \\ United States Department of Agriculture, stephen.rehner@ars.usda.gov \\ Fernando E. Vega \\ United States Department of Agriculture
}

Follow this and additional works at: https://digitalcommons.unl.edu/usdaarsfacpub

Part of the Agricultural Science Commons

\footnotetext{
Posada, Francisco; Aime, M. Catherine; Peterson, Stephen W.; Rehner, Stephen A.; and Vega, Fernando E., "Inoculation of coffee plants with the fungal entomopathogen Beauveria bassiana (Ascomycota: Hypocreales)" (2007). Publications from USDA-ARS / UNL Faculty. 372.

https://digitalcommons.unl.edu/usdaarsfacpub/372
}

This Article is brought to you for free and open access by the U.S. Department of Agriculture: Agricultural Research Service, Lincoln, Nebraska at DigitalCommons@University of Nebraska - Lincoln. It has been accepted for inclusion in Publications from USDA-ARS / UNL Faculty by an authorized administrator of DigitalCommons@University of Nebraska - Lincoln. 


\title{
Inoculation of coffee plants with the fungal entomopathogen Beauveria bassiana (Ascomycota: Hypocreales)
}

\author{
Francisco POSADA ${ }^{a}$, M. Catherine AIME ${ }^{b}$, Stephen W. PETERSON ${ }^{c}$, \\ Stephen A. REHNER ${ }^{a}$, Fernando E. VEGA ${ }^{a, *}$ \\ ansect Biocontrol Laboratory, US Department of Agriculture, Agricultural Research Service, Building 011A, \\ BARC-W, Beltsuille, MD 20705, USA \\ ${ }^{\mathrm{b}}$ Systematic Botany and Mycology Laboratory, US Department of Agriculture, Agricultural Research Service, \\ Building 011A, BARC-W, Beltsville, MD 20705, USA \\ ${ }^{\mathrm{C}}$ Microbial Genomics and Bioprocessing Research Unit, National Center for Agricultural Utilization Research, \\ US Department of Agriculture, Agricultural Research Service, 1815 North University Street, Peoria, IL 61604, USA
}

\section{A R T I C L E I N F O}

\section{Article history:}

Received 11 July 2006

Received in revised form

19 January 2007

Accepted 8 March 2007

Published online 15 March 2007

Corresponding Editor:

Richard A. Humber

Keywords:

Coffea

Coffee berry borer

Endophytes

Hypothenemus

\begin{abstract}
A B S T R A C T
The entomopathogenic fungus Beauveria bassiana was established in coffee seedlings after fungal spore suspensions were applied as foliar sprays, stem injections, or soil drenches. Direct injection yielded the highest post-inoculation recovery of endophytic B. bassiana. Establishment, based on percent recovery of B. bassiana, decreased as time post-inoculation increased in all treatments. Several other endophytes were isolated from the seedlings and could have negatively influenced establishment of B. bassiana. The recovery of B. bassiana from sites distant from the point of inoculation indicates that the fungus has the potential to move throughout the plant.
\end{abstract}

Published by Elsevier Ltd on behalf of The British Mycological Society.

\section{Introduction}

The coffee berry borer Hypothenemus hampei (Coleoptera: Curculionidae) is the most important coffee pest worldwide (Le Pelley 1968). Adult females deposit their eggs in galleries inside the coffee berry, with larval feeding on the seeds, reducing yields as well as quality. Pest management strategies against the coffee berry borer have met limited success mainly due to the cryptic life-cycle of the insect inside the berry. These strategies have included the use of chemical insecticides (Mansingh 1991; Carrillo et al. 1989; Godoy et al. 1984; Villalba et al. 1995), the application of entomopathogenic fungi (Posada 1998; de la Rosa et al. 2000; Haraprasad et al. 2001; Posada et al. 2004), the release of parasitoids (Aristizabal et al. 2004; Quintero et al. 1998), and cultural practices emphasizing frequent harvest of ripe and infested berries in order to interrupt the life cycle (Bustillo et al. 1998).

Another possible pest management alternative involves the inoculation and endophytic establishment in coffee plants with the entomopathogenic fungus Beauveria bassiana (Ascomycota: Hypocreales). B. bassiana has been reported as an endophyte in maize (Vakili 1990; Bing \& Lewis 1991, 1992a, 1992b;

\footnotetext{
* Corresponding author.

E-mail address: Fernando.Vega@ars.usda.gov 0953-7562/\$ - see front matter Published by Elsevier Ltd on behalf of The British Mycological Society. doi:10.1016/j.mycres.2007.03.006 
Lomer et al. 1997; Cherry et al. 1999, 2004; Wagner \& Lewis 2000; Arnold \& Lewis 2005), tomato (Leckie 2002), potato, cotton, cocklebur, and jimsonweed (Jones 1994), Theobroma gileri (Evans et al. 2003), in the bark of Carpinus caroliniana (Bills \& Polishook 1991), in seeds and needles of Pinus monticola (Ganley \& Newcombe 2005), in opium poppies (Quesada-Moraga et al. 2006), and in coffee berries from Colombia (Vega et al. unpubl.). In maize, endophytic B. bassiana was reported as a mortality agent against the European corn borer Ostrinia nubinalis (Bing \& Lewis 1991; Arnold \& Lewis 2005).

Recently, positive B. bassiana detection was attained in in vitro grown cocoa (Posada \& Vega 2006a) and coffee seedlings (Posada \& Vega 2006b) inoculated on the radicle and evaluated 30 and $60 \mathrm{~d}$ post-inoculation. The objective of this study was to evaluate whether B. bassiana can be established as an endophyte in coffee seedlings using different fungal isolates and inoculation methods. Our ultimate goal is to establish B. bassiana as an endophyte in the coffee berry, which is the target site for the coffee berry borer.

\section{Materials and methods}

\section{Isolates}

Four Beauveria bassiana isolates were used in this study. Three were obtained from the ARS Collection of Entomopathogen Fungal Cultures (ARSEF; http://www.ars.usda.gov/is/np/systematics/fungibact.htm): ARSEF 5486 from Ivory Coast; ARSEF 2687 from Kenya; and ARSEF 1480 from Brazil. These were previously isolated from the coffee berry borer and selected for this study from a screening of single spore isolates (Posada \& Vega 2005). The fourth isolate was a multispore isolate obtained as an endophyte from healthy coffee berries from Colombia and identified as CS16-1 (Insect Biocontrol Laboratory Culture Collection = IBL03032). Isolates ARSEF 5486, ARSEF 1040, and CS16-1 (IBL03032) were previously determined to belong to AFNEO_1, a clade of generalist entomopathogens that is widely established throughout the neotropics and in coffee plantations in western equatorial Africa (Rehner et al. 2006). ARSEF 2687 has been determined to have affinities to the clade Asia 4 (Rehner et al. 2006), however, this isolate is the only member of this lineage that has been examined to date, thus its phylogenetic position and status within the B. bassiana complex is unresolved (Rehner unpublished).

The isolates were cultured on yeast malt agar (YMA; Sigma Aldrich, St Louis, MO) to which $0.1 \%$ stock antibiotics was added. The stock antibiotic solution consisted of $0.02 \mathrm{~g}$ each of tetracycline, streptomycin and penicillin, dissolved in $10 \mathrm{ml}$ sterile, distilled water, filter-sterilized through a $0.2 \mu \mathrm{m}$ filter (Nalgene Disposable Filterware, Nalge Nunc International Rochester, NY); from this, $1 \mathrm{ml}$ was added per litre of medium. The cultures were approximately one-month old when used, and a germination test was conducted before inoculating the plants. For the test, a low concentration of conidia was suspended in $0.1 \%$ Triton X-100 (Sigma Aldrich) and from this stock a $15 \mu \mathrm{l}$ aliquot was plated on $2.5 \%$ Noble agar (Becton Dickinson, Sparks, MD). The aliquot was spread with a sterile glass rod onto the medium surface and incubated in the dark at $25 \pm 2{ }^{\circ} \mathrm{C}$ for $24 \mathrm{~h}$ after which $25 \%$ lactophenol blue solution (Fluka Chemie, Buchs, Switzerland) was added to stop germination, and three groups of 100 conidia selected at random were assessed for germination (Vélez et al. 1997; Goettel \& Inglis 1997).

\section{Coffee plants}

The coffee seedlings used for inoculation were obtained from The Behnke Nurseries, Beltsville, MD. Seedlings were transplanted to sterile potting media, and at the time of inoculation, had on average eight pairs of leaves and were ca $20 \mathrm{~cm}$ tall.

\section{Inoculation methods}

Three inoculation methods were tested: foliar spray, stem injection, and soil drench. For each isolate a spore stock suspension was prepared in $0.1 \%$ Triton $\mathrm{X}-100$, and the spore concentration was adjusted to $1 \times 10^{8}$ conidia $\mathrm{ml}^{-1}$. The foliar spray inoculation method was performed with a hand sprayer (Spraymaster Consolidated Plastics, Twinsburg, $\mathrm{OH}$ ), and an average of $5 \mathrm{ml}$ per plant was applied. The spray was directed mainly to the leaves but also incidentally coated the stems. To avoid conidial runoff to the soil, the top of each pot was covered with aluminum foil. For stem injection inoculations, a hole was made on the stem using a $21 \mathrm{G}$ sterile disposable hypodermic needle to facilitate injection of $1 \mu \mathrm{l}$ conidial suspension with a Hamilton syringe (Hamilton, Reno, NV). For the drench inoculation method, $10 \mathrm{ml}$ of the spore suspension was applied to the surface of the soil in each pot. Controls received sterile $0.1 \%$ Triton $\mathrm{X}-100$ applied in the same way as each treatment mentioned above.

After spraying, each plant was covered with a plastic bag for $24 \mathrm{~h}$ to maintain a high level of humidity. For the plants that were treated with either drench or injection no coverage was needed as the fungus was applied on the soil or inside the plant, where humidity is naturally high. The experiment was run for a total of eight months, and the recovery of $B$. bassiana and other endophytic fungi and bacteria was evaluated by culture methods at two, four, six, and eight months postinoculation.

\section{Experimental design}

The experiment was run as a completely randomized design where the treatments were four Beauveria bassiana isolates, three methods of inoculation (foliar spray, stem injection, soil drench), and the corresponding controls. After inoculation, the pots containing the plants were randomized and kept in plant growth chambers (Model E-36L, Percival Scientific, Boone, IA) at $22 \pm 2{ }^{\circ} \mathrm{C}$ and 12:12 photoperiod. The plants were fertilized monthly using $25 \mathrm{ml}$ Miracle-Gro (Scotts MiracleGro Products, Marysville, OH) plus chelated iron $10 \%$ (Becker Underwood, Ames, IA), and they were watered every $2 \mathrm{~d}$.

\section{Evaluation for presence of Beauveria bassiana}

For each evaluation at two, four, six, and eight months postinoculation, three separate plants per treatment per isolate were used. The pots containing coffee plants were moved from the growth chambers to the laboratory, where the plants 
were uprooted and individually washed out with running tap water. From each plant, two leaves, two pieces of stem and two pieces of root were surface sterilized in a $0.5 \%$ sodium hypochlorite suspension for $2 \mathrm{~min}, 70 \%$ ethanol for $2 \mathrm{~min}$, and rinsed in sterile autoclaved water and dried on sterile towel paper. The final rinse water was plated to determine whether the sterilization process was successful in eliminating epiphytic microorganisms. The leaves were randomly selected from the middle section of the seedling, i.e. no leaves were selected from the apical area or from the basal area. Similarly, two parts of the stem were sampled, one towards the middle of the plant and the second one closer to the soil surface. As for roots, the tap root was sampled by dividing it in two parts, but the root tips were not sampled.

Tissues were cut using a sterile scalpel and forceps into pieces averaging $2 \times 3 \mathrm{~mm}^{2}$ and six pieces were plated on two $60 \mathrm{~mm}$ diam Petri dishes containing YMA plus three antibiotics and kept at $22 \pm 3^{\circ} \mathrm{C}$. Two hundred and thirty-four Petri dishes were plated for each evaluation period containing a total of 1404 subsamples of plant tissues. A total of 156 plants and 5616 tissue subsamples were evaluated during the course of the experiment.

The results are summarized in Tables 1-3 and are expressed as the percentage of plants positive for the presence of Beauveria bassiana after inoculation. The proportion of coffee plant tissues on which $B$. bassiana was found was also evaluated. At the time of the second evaluation the incidence of B. bassiana had dropped sharply, and it was decided to increase the number of tissue samples per plant in the remaining two evaluations. For the eight-month post-inoculation evaluation,
Table 2 - Number of fungal and bacterial isolates obtained as endophytes from coffee plants inoculated with Beauveria bassiana throughout four evaluations

\begin{tabular}{lrrrrrr} 
Evaluation & Total & \multicolumn{2}{c}{ Fungi } & & \multicolumn{2}{c}{ Bacteria } \\
\cline { 3 - 4 } \cline { 7 - 7 } & & $n$ & $\%$ & & $N$ & $\%$ \\
\hline Two months & 1073 & 632 & 58.9 & & 441 & 41.1 \\
Four months & 876 & 249 & 28.4 & & 627 & 71.7 \\
Six months & 718 & 652 & 90.8 & & 66 & 9.2 \\
Eight months & 1001 & 847 & 84.6 & & 154 & 15.4 \\
\hline
\end{tabular}

in addition to the regular YMA plus antibiotic media, two additional replicate dishes per treatment containing a selective growth-suppressing medium that favours B. bassiana (Chase et al. 1986) were used to reduce competition of other endophytic fungi likely to out-compete B. bassiana during reisolation. Endophytic fungi other than B. bassiana isolated two and four months post-inoculation were sequenced (see below). The diversity of fungi was estimated using the Shannon index (Fowler et al. 1998; Magurran 2004).

\section{Inoculation of coffee seeds}

An experiment was conducted to evaluate the feasibility of inoculating coffee seeds (Colombia variety) with Beauveria bassiana conidia. Coffee seeds were soaked for $24 \mathrm{~h}$ in a conidial suspension at a final concentration of $1 \times 10^{8}$ conidia $\mathrm{ml}^{-1}$ prepared from each of the four isolates mentioned above. The control was soaked in a sterile solution of $0.1 \%$ Triton X-100.

Table 1 - Incidence of four Beauveria bassiana isolates in coffee plants two, four, and six months post-inoculation using spray, injections, or drenches

\begin{tabular}{|c|c|c|c|c|c|c|c|c|c|c|c|c|c|c|c|c|c|c|c|c|c|}
\hline \multirow[t]{3}{*}{ Isolate } & \multirow[t]{3}{*}{$n^{a}$} & \multicolumn{6}{|c|}{ Drench } & \multicolumn{6}{|c|}{ Injection } & \multicolumn{6}{|c|}{ Spraying } & \multicolumn{2}{|c|}{ Total } \\
\hline & & \multicolumn{2}{|c|}{ Leaves } & \multicolumn{2}{|c|}{ Stems } & \multicolumn{2}{|c|}{ Roots } & \multicolumn{2}{|c|}{ Leaves } & \multicolumn{2}{|c|}{ Stems } & \multicolumn{2}{|c|}{ Roots } & \multicolumn{2}{|c|}{ Leaves } & \multicolumn{2}{|c|}{ Stems } & \multicolumn{2}{|c|}{ Roots } & & \\
\hline & & + & $\%$ & + & $\%$ & + & $\%$ & + & $\%$ & + & $\%$ & + & $\%$ & + & $\%$ & + & $\%$ & + & $\%$ & + & $\%$ \\
\hline \multicolumn{22}{|c|}{ Two months } \\
\hline 1480 & 3 & 0 & 0 & 0 & 0 & 1 & 33.3 & 0 & 0 & 3 & 100 & 0 & 0 & 0 & 0 & 0 & 0 & 0 & 0 & 4 & 44.4 \\
\hline CS16-1 & 3 & 0 & 0 & 0 & 0 & 1 & 33.3 & 0 & 0 & 1 & 33.3 & 0 & 0 & 0 & 0 & 0 & 0 & 0 & 0 & 2 & 22.2 \\
\hline 5486 & 3 & 0 & 0 & 1 & 33.3 & 0 & 0 & 0 & 0 & 1 & 33.3 & 0 & 0 & 0 & 0 & 0 & 0 & 0 & 0 & 2 & 22.2 \\
\hline 2687 & 3 & 0 & 0 & 0 & 0 & 0 & 0 & 0 & 0 & 2 & 66.7 & 0 & 0 & 1 & 33.3 & 0 & 0 & 0 & 0 & 3 & 33.3 \\
\hline Total & & 0 & 0 & 1 & 8.3 & 2 & 16.7 & 0 & 0 & 7 & 58.3 & 0 & 0 & 1 & 8.3 & 0 & 0 & 0 & 0 & 11 & 30.6 \\
\hline \multicolumn{22}{|c|}{ Four months } \\
\hline 1480 & 3 & 0 & 0 & 0 & 0 & 0 & 0 & 0 & 0 & 2 & 66.7 & 0 & 0 & 0 & 0 & 0 & 0 & 0 & 0 & 2 & 22.2 \\
\hline CS16-1 & 3 & 0 & 0 & 0 & 0 & 0 & 0 & 0 & 0 & 0 & 0 & 0 & 0 & 0 & 0 & 0 & 0 & 0 & 0 & 0 & 0 \\
\hline 5486 & 3 & 0 & 0 & 0 & 0 & 0 & 0 & 0 & 0 & 0 & 0 & 0 & 0 & 0 & 0 & 0 & 0 & 0 & 0 & 0 & 0 \\
\hline 2687 & 3 & 0 & 0 & 0 & 0 & 0 & 0 & 0 & 0 & 0 & 0 & 0 & 0 & 0 & 0 & 0 & 0 & 0 & 0 & 0 & 0 \\
\hline Total & & 0 & 0 & 0 & 0 & 0 & 0 & 0 & 0 & 2 & 16.7 & 0 & 0 & 0 & 0 & 0 & 0 & 0 & 0 & 2 & 5.5 \\
\hline \multicolumn{22}{|c|}{ Six months } \\
\hline 1480 & 3 & 0 & 0 & 0 & 0 & 0 & 0 & 0 & 0 & 0 & 0 & 0 & 0 & 0 & 0 & 0 & 0 & 0 & 0 & 0 & 0 \\
\hline CS16-1 & 3 & 0 & 0 & 0 & 0 & 0 & 0 & 0 & 0 & 0 & 0 & 0 & 0 & 0 & 0 & 0 & 0 & 0 & 0 & 0 & 0 \\
\hline 5486 & 3 & 0 & 0 & 0 & 0 & 0 & 0 & 0 & 0 & 0 & 0 & 1 & 33.3 & 0 & 0 & 0 & 0 & 0 & 0 & 1 & 11.1 \\
\hline 2687 & 3 & 0 & 0 & 0 & 0 & 0 & 0 & 0 & 0 & 0 & 0 & 0 & 0 & 0 & 0 & 0 & 0 & 0 & 0 & 0 & 0 \\
\hline Total & & 0 & 0 & 0 & 0 & 0 & 0 & 0 & 0 & 0 & 0 & 1 & 8.3 & 0 & 0 & 0 & 0 & 0 & 0 & 1 & 2.7 \\
\hline
\end{tabular}

Beauveria bassiana was not detected eight months post-inoculation.

a There were three replicates for each isolate by treatment combination: three different plants were used, and within each plant, leaves, stems and roots were assessed for B. bassiana presence. 
Table 3 - Endophytic fungi isolated from coffee plants two and four months post-inoculation with Beauveria bassiana

\begin{tabular}{|c|c|c|c|c|c|c|c|c|c|c|c|c|c|c|c|c|c|c|c|}
\hline \multirow[t]{3}{*}{ Endophyte } & \multirow[t]{3}{*}{ GenBank no. } & \multicolumn{9}{|c|}{ Two months post-inoculation } & \multicolumn{9}{|c|}{ Four months post-inoculation } \\
\hline & & \multirow[t]{2}{*}{$n$} & \multicolumn{2}{|c|}{ Total } & \multicolumn{2}{|c|}{ Leaves } & \multicolumn{2}{|c|}{ Stems } & \multicolumn{2}{|c|}{ Roots } & \multirow[t]{2}{*}{$n$} & \multicolumn{2}{|c|}{ Total } & \multicolumn{2}{|c|}{ Leaves } & \multicolumn{2}{|c|}{ Stems } & \multicolumn{2}{|c|}{ Roots } \\
\hline & & & $n$ & $\%$ & $\bar{n}$ & $\%$ & $n$ & $\%$ & $n$ & $\%$ & & $n$ & $\%$ & $n$ & $\%$ & $n$ & $\%$ & $n$ & $\%$ \\
\hline Alternaria sp. & DQ682562 & 632 & 1 & 0.2 & 1 & 0.2 & 0 & 0.0 & 0 & 0.0 & 0 & 0 & 0.0 & 0 & 0 & 0 & 0 & 0 & 0 \\
\hline Arthopyrenaceae & DQ682563 & 0 & 0 & 0.0 & 0 & 0.0 & 0 & 0.0 & 0 & 0.0 & 249 & 3 & 1.2 & 0 & 0.0 & 3 & 1.2 & 0 & 0.0 \\
\hline Aspergillus tamari & DQ682564 & 0 & 0 & 0.0 & 0 & 0.0 & 0 & 0.0 & 0 & 0.0 & 249 & 1 & 0.4 & 0 & 0.0 & 0 & 0.0 & 1 & 0.4 \\
\hline A. westerdijkiae & DQ682565 & 632 & 1 & 0.2 & 0 & 0.0 & 0 & 0.0 & 1 & 0.2 & 0 & 0 & 0.0 & 0 & 0 & 0 & 0 & 0 & 0 \\
\hline Beauveria bassiana & DQ682566 & 632 & 14 & 2.2 & 1 & 0.2 & 8 & 1.3 & 5 & 0.8 & 249 & 8 & 3.2 & 0 & 0 & 8 & 3.2 & 0 & 0 \\
\hline Bionectriaceae & DQ682567 & 632 & 1 & 0.2 & 1 & 0.2 & 0 & 0.0 & 0 & 0.0 & 249 & 8 & 3.2 & 0 & 0 & 7 & 2.8 & 1 & 0.4 \\
\hline Chaetomium sp. & DQ682568 & 632 & 2 & 0.3 & 2 & 0.3 & 0 & 0.0 & 0 & 0.0 & 0 & 0 & 0.0 & 0 & 0 & 0 & 0 & 0 & 0 \\
\hline Cladosporium cf. sphaerospermum & DQ682569 & 0 & 0 & 0.0 & 0 & 0.0 & 0 & 0.0 & 0 & 0.0 & 249 & 6 & 2.4 & 6 & 2.4 & 0 & 0.0 & 0 & 0.0 \\
\hline Cladosporium sp. & DQ682570 & 0 & 0 & 0.0 & 0 & 0.0 & 0 & 0.0 & 0 & 0.0 & 249 & 1 & 0.4 & 0 & 0.0 & 1 & 0.4 & 0 & 0.0 \\
\hline Clavicipitaceae & DQ682571 & 0 & 0 & 0.0 & 0 & 0.0 & 0 & 0.0 & 0 & 0.0 & 249 & 6 & 2.4 & 1 & 0.4 & 0 & 0.0 & 5 & 2.0 \\
\hline Colletotrichum gloeosporoides complex & DQ682572 & 632 & 12 & 1.9 & 0 & 0.0 & 11 & 1.7 & 1 & 0.2 & 0 & 0 & 0.0 & 0 & 0 & 0 & 0 & 0 & 0 \\
\hline Cylindrocarpon sp. & DQ682573 & 632 & 51 & 8.1 & 0 & 0.0 & 4 & 0.6 & 47 & 7.4 & 249 & 20 & 8.0 & 0 & 0 & 0 & 0 & 20 & 8 \\
\hline Exobasidiomycetidae & DQ682574 & 632 & 1 & 0.2 & 1 & 0.2 & 0 & 0.0 & 0 & 0.0 & 0 & 0 & 0.0 & 0 & 0 & 0 & 0 & 0 & 0 \\
\hline Exophiala sp. & DQ682575 & 632 & 2 & 0.3 & 0 & 0.0 & 0 & 0.0 & 2 & 0.3 & 0 & 0 & 0.0 & 0 & 0 & 0 & 0 & 0 & 0 \\
\hline Fusarium cf. oxysporum f. sp. vasinfectum & DQ682576 & 632 & 174 & 27.5 & 0 & 0.0 & 73 & 11.6 & 101 & 16.0 & 249 & 24 & 9.6 & 1 & 0.4 & 6 & 2.4 & 17 & 6.8 \\
\hline F. oxysporum complex (1) & DQ682577 & 632 & 5 & 0.8 & 0 & 0.0 & 5 & 0.8 & 0 & 0.0 & 249 & 10 & 4.0 & 0 & 0.0 & 2 & 0.8 & 8 & 3.2 \\
\hline F. oxysporum complex (2) & DQ682579 & 632 & 8 & 1.3 & 0 & 0.0 & 1 & 0.2 & 7 & 1.1 & 249 & 2 & 0.8 & 0 & 0 & 2 & 0.8 & 0 & 0 \\
\hline Fusarium sp. (1) & DQ682581 & 632 & 41 & 6.5 & 0 & 0.0 & 40 & 6.3 & 1 & 0.2 & 0 & 0 & 0.0 & 0 & 0 & 0 & 0 & 0 & 0 \\
\hline Fusarium sp. (2) & DQ682582 & 632 & 56 & 8.9 & 1 & 0.2 & 26 & 4.1 & 29 & 4.6 & 0 & 0 & 0.0 & 0 & 0 & 0 & 0 & 0 & 0 \\
\hline Fusarium sp. (Lateritium clade 1 ) & DQ682580 & 632 & 4 & 0.6 & 0 & 0.0 & 0 & 0.0 & 4 & 0.6 & 0 & 0 & 0.0 & 0 & 0 & 0 & 0 & 0 & 0 \\
\hline Hypocrea sp. (VI Lutea clade) & DQ682583 & 632 & 5 & 0.8 & 0 & 0.0 & 1 & 0.2 & 4 & 0.6 & 0 & 0 & 0.0 & 0 & 0 & 0 & 0 & 0 & 0 \\
\hline Hypocreales sp. (1) & DQ682584 & 632 & 5 & 0.8 & 5 & 0.8 & 0 & 0.0 & 0 & 0.0 & 0 & 0 & 0.0 & 0 & 0 & 0 & 0 & 0 & 0 \\
\hline Hypocreales sp. (2) & DQ682585 & 0 & 0 & 0.0 & 0 & 0.0 & 0 & 0.0 & 0 & 0.0 & 249 & 1 & 0.4 & 0 & 0.0 & 0 & 0.0 & 1 & 0.4 \\
\hline Macrophomina sp. & DQ682587 & 632 & 4 & 0.6 & 1 & 0.2 & 3 & 0.5 & 0 & 0.0 & 0 & 0 & 0.0 & 0 & 0 & 0 & 0 & 0 & 0 \\
\hline Paecilomyces sp. & DQ682588 & 632 & 4 & 0.6 & 0 & 0.0 & 1 & 0.2 & 3 & 0.5 & 249 & 4 & 1.6 & 0 & 0 & 4 & 1.6 & 0 & 0 \\
\hline Penicillium citrinum & DQ682589 & 632 & 194 & 30.7 & 8 & 1.3 & 156 & 24.7 & 30 & 4.7 & 249 & 80 & 32.1 & 0 & 0 & 62 & 24.9 & 18 & 7.2 \\
\hline P. brevicompactum & DQ682592 & 632 & 6 & 0.9 & 0 & 0.0 & 0 & 0.0 & 6 & 0.9 & 0 & 0 & 0.0 & 0 & 0 & 0 & 0 & 0 & 0 \\
\hline $\begin{array}{l}\text { P. cecidicola } \\
\end{array}$ & N/A & 632 & 4 & 0.6 & 0 & 0.0 & 4 & 0.6 & 0 & 0.0 & 0 & 0 & 0.0 & 0 & 0 & 0 & 0 & 0 & 0 \\
\hline P. glabrum & DQ682590 & 632 & 1 & 0.2 & 0 & 0.0 & 0 & 0.0 & 1 & 0.2 & 249 & 1 & 0.4 & 0 & 0 & 0 & 0 & 1 & 0.4 \\
\hline P. janthinellum & DQ682591 & 0 & 0 & 0.0 & 0 & 0.0 & 0 & 0.0 & 0 & 0.0 & 249 & 8 & 3.2 & 0 & 0.0 & 0 & 0.0 & 8 & 3.2 \\
\hline Penicillium sp. near daleae & DQ682593 & 0 & 0 & 0.0 & 0 & 0.0 & 0 & 0.0 & 0 & 0.0 & 249 & 8 & 3.2 & 0 & 0 & 2 & 0.8 & 6 & 2.4 \\
\hline P. steckii & DQ682594 & 632 & 1 & 0.2 & 0 & 0.0 & 0 & 0.0 & 1 & 0.2 & 249 & 1 & 0.4 & 0 & 0 & 0 & 0 & 1 & 0.4 \\
\hline P. toxicarium & DQ682595 & 632 & 1 & 0.2 & 0 & 0.0 & 1 & 0.2 & 0 & 0.0 & 0 & 0 & 0.0 & 0 & 0 & 0 & 0 & 0 & 0 \\
\hline Phyllachoraceae & DQ682596 & 0 & 0 & 0.0 & 0 & 0.0 & 0 & 0.0 & 0 & 0.0 & 249 & 3 & 1.2 & 0 & 0.0 & 0 & 0.0 & 3 & 1.2 \\
\hline Plectosphaerella sp. & DQ682597 & 0 & 0 & 0.0 & 0 & 0.0 & 0 & 0.0 & 0 & 0.0 & 249 & 1 & 0.4 & 0 & 0.0 & 0 & 0.0 & 1 & 0.4 \\
\hline Pleosporales sp. & DQ682598 & 632 & 3 & 0.5 & 1 & 0.2 & 0 & 0.0 & 2 & 0.3 & 0 & 0 & 0.0 & 0 & 0 & 0 & 0 & 0 & 0 \\
\hline Pseudallescheria cf. boydii & DQ682599 & 632 & 3 & 0.5 & 0 & 0.0 & 0 & 0.0 & 3 & 0.5 & 0 & 0 & 0.0 & 0 & 0 & 0 & 0 & 0 & 0 \\
\hline Rhizopycnis sp. & DQ682600 & 0 & 0 & 0.0 & 0 & 0.0 & 0 & 0.0 & 0 & 0.0 & 249 & 3 & 1.2 & 0 & 0.0 & 0 & 0.0 & 3 & 1.2 \\
\hline Trichoderma sp. & DQ682604 & 632 & 1 & 0.2 & 0 & 0.0 & 1 & 0.2 & 0 & 0.0 & 249 & 30 & 6.4 & 0 & 0 & 1 & 1.6 & 29 & 4.8 \\
\hline T. hamatum & DQ682602 & 632 & 19 & 3.0 & 0 & 0.0 & 5 & 0.8 & 14 & 2.2 & 249 & 18 & 7.2 & 0 & 0.0 & 4 & 1.6 & 14 & 5.6 \\
\hline T. harzianum & DQ682603 & 0 & 0 & 0.0 & 0 & 0.0 & 0 & 0.0 & 0 & 0.0 & 249 & 2 & 0.8 & 0 & 0.0 & 0 & 0.0 & 2 & 0.8 \\
\hline Not identified & & 632 & 8 & 1.3 & 0 & 0.0 & 0 & 0.0 & 8 & 1.3 & 0 & 0 & 0.0 & 0 & 0.0 & 0 & 0.0 & 0 & 0.0 \\
\hline
\end{tabular}

Percentages are based on 632 positive fungal isolations two months post-inoculation and 249 four months post-inoculation. 
After soaking, seeds were germinated on a tray containing moistened sterile sand and covered with a black plastic bag to maintain humidity. The sand was watered every $2 \mathrm{~d}$. After emergence of the cotyledon, each seedling was planted individually in a pot with a mixture of sterile potting media and sand. Evaluations were performed two, four, and six months post-planting, and each time two plants were sampled per isolate. Leaf, roots, and stem tissues were surface sterilized and plated as previously described.

\section{Fungal and bacterial endophytes}

The number of fungal and bacterial endophytes present in the tissues sampled was assessed at each evaluation period. Fungi other than Beauveria bassiana isolated from plants two and four months post-inoculation were sequenced (described below) and compared with records deposited in GenBank. All fungal isolates have been deposited at the Insect Biocontrol Laboratory (USDA, ARS) fungal collection. Bacteria were classified based on colony shape and colour as morpho-species.

\section{Fungal endophyte DNA extraction}

Fungal isolates were individually grown on potato dextrose broth (Becton Dickinson, Sparks, MD) at $25^{\circ} \mathrm{C}$ and $150 \mathrm{rev} \mathrm{min}^{-1}$ in an Innova 4000 Incubator Shaker (New Brunswick Scientific, Edison, NJ). At $8 \mathrm{~d}$, the fungal mass was transferred to $50 \mathrm{ml}$ sterile tubes, centrifuged for $10 \mathrm{~min}$ at $10,000 \mathrm{rev} \mathrm{min}^{-1}$, and the supernatant discarded. This was followed by washing with sterile, distilled water and centrifuging again for $10 \mathrm{~min}$ at $10,000 \mathrm{rev} \mathrm{min}^{-1}$. The fungal mass was removed from the sterile tube in the laminar flow hood, dried on sterile filter paper, transferred to $1.5 \mathrm{ml}$ sterile Eppendorf tubes, and lyophilized. Samples were stored at $-80^{\circ} \mathrm{C}$.

For DNA extraction, approximately $50 \mathrm{mg}$ lyophilized mycelium was placed in a $2 \mathrm{ml}$ microcentrifuge tube with ca $0.2 \mathrm{ml} 1.0 \mathrm{~mm}$ diam zirconia-glass beads (BIOSPEC, Bartlesville, OK). The mycelium was crushed with a plastic pestle and further ground in a FastPrep-120 sample grinder (Q-BIOgene, Irvine, CA) for $3 \mathrm{~s}$ at the maximum speed setting of 6 . The powdered mycelium was suspended in $700 \mu$ l detergent solution ( $2 \mathrm{~m} \mathrm{NaCl}, 0.4 \%$ (w/v) deoxycholic acid-sodium salt, $1 \%(\mathrm{w} / \mathrm{v})$ polyoxyethylene 20 cetyl ether) and then agitated for $14 \mathrm{~s}$ in the Fast-Prep at maximum speed. Vials were incubated $5 \mathrm{~min}$ at $55^{\circ} \mathrm{C}$ in a heat block and then centrifuged at $10,600 \mathrm{rev} \mathrm{min}^{-1}$ for $5 \mathrm{~min}$ followed by emulsion with $700 \mu \mathrm{l}$ chloroform-isopropyl and centrifugation at $10,600 \mathrm{rev} \mathrm{min}^{-1}$ for $5 \mathrm{~min}$. The aqueous phase was transferred to a clean tube to which an equal volume of $6 \mathrm{~m}$ guanidinium thiocyanate was added. Fifteen microlitres of silica powder was suspended in the solution by gently mixing for $5 \mathrm{~min}$ at room temperature, followed by $3 \mathrm{~s}$ centrifugation, after which the supernatant was discarded. The glass powder was rinsed twice by suspending in $750 \mu \mathrm{l}$ ethanol buffer $(10 \mathrm{~mm}$ Tris-HCl, pH 8, 0.1 mm EDTA, 50 \% ethanol) with a disposable transfer pipette, then collected by centrifugation, and the supernatant discarded; the glass powder pellet was dried on a heat block at $55^{\circ} \mathrm{C}$ for $5-10 \mathrm{~min}$. The glass powder was rehydrated with $105 \mu$ l ultra-pure water and the genomic DNA eluted from the silica matrix by incubating on a heat block at $55^{\circ} \mathrm{C}$ for $5-10 \mathrm{~min}$. After vortexing and centrifugation, $100 \mu \mathrm{l}$ of the aqueous supernatant was transferred to a clean tube.

\section{Fungal endophyte DNA sequencing and analyses}

The ITS region of the nu-rDNA repeat was sequenced for each isolate; primers ITS1-F (fungal-specific) (Gardes \& Bruns 1993) and ITS4 (White et al. 1990) were used for both amplification and sequencing. PCRs were performed in $25 \mu \mathrm{l}$ reaction volumes with $12.5 \mu \mathrm{l}$ PCR Master Mix (Promega, Madison, $\mathrm{WI}), 1.25 \mu \mathrm{l}$ each of $10 \mu \mathrm{M}$ primers, and $10 \mu \mathrm{l}$ of diluted (10- to 100-fold) DNA template. Amplification was achieved with an initial denaturation step of $5 \mathrm{~min}$ at $94^{\circ} \mathrm{C} ; 35$ cycles of $30 \mathrm{~s}$ at $94{ }^{\circ} \mathrm{C}, 45 \mathrm{~s}$ at $50^{\circ} \mathrm{C}$, and $45 \mathrm{~s}$ at $72{ }^{\circ} \mathrm{C}$; and a final extension of $7 \mathrm{~min}$ at $72^{\circ} \mathrm{C}$. The PCR products were cleaned with Montage PCR Centrifugal Filter Devices (Millipore, Billerica, MD) according to the manufacturer's protocol. Cleaned PCR products were sequenced with BigDye Terminator sequencing enzyme version 3.1 (Applied Biosystems, Foster City, CA) in the reaction: $2 \mu$ l of diluted BigDye in a 1:3 dilution of BigDye:dilution buffer ( $400 \mathrm{~mm}$ Tris $\mathrm{pH} 8,10 \mathrm{~mm} \mathrm{MgCl}_{2}$ ); $0.3 \mu \mathrm{l}$ of $10 \mu \mathrm{m}$ primer; 10-20 ng cleaned PCR template; and water to a $5 \mu$ l total reaction volume. Cycle sequencing parameters consisted of a 2 min denaturation step at $94^{\circ} \mathrm{C}$, then 35 cycles of $94^{\circ} \mathrm{C}$ for $39 \mathrm{~s}, 50^{\circ} \mathrm{C}$ for $15 \mathrm{~s}$, and $60^{\circ} \mathrm{C}$ for $4 \mathrm{~min}$. Sequencing reactions were cleaned by ethanol precipitation and sequenced on an ABI 3100 Genetic Analyser (Applied Biosystems). Sequencing reactions were edited and contiguous sequences for each isolate were assembled in Sequencher version 4.1.4 (Gene Codes, Ann Arbor, MI).

Initial identification of isolates was obtained by BLAST analysis (http://www.ncbi.nlm.nih.gov/BLAST/). Refinements on species identification were performed for various groups: Colletotrichum was aligned using a Colleotrichum sequence database at the USDA, ARS Systematic Botany and Mycology Laboratory (Beltsville, MD); Trichoderma/Hypocrea species were identified using TrichOKey (http://www.isth.info/tools/mol key/index.php?do=unset; Druzhinina et al. 2006). For any ITS sequence leading to Fusarium, an EF1- $\alpha$ sequence was obtained using primers developed by Rehner \& Buckley (2005) followed by on-line sequence comparisons against the Fusarium Database (http://fusarium.cbio.psu.edu/). Penicillium and Aspergillus species were further identified using unpublished sequences from ex-type isolates (S.W. Peterson). Multilocus DNA sequence studies with genealogical concordance analysis (Taylor et al. 2000) identify ITS genotypes included in particular species, but such studies are published only for some species in these genera. For those species where multilocus studies are not available, exact ITS sequence matches to type sequences were considered reliable identification and differences of one to two bases were probable identifications. Larger differences were considered to be non-identifications. DNA sequences have been deposited in GenBank (Table 3).

\section{Results}

Conidial viability of the four Beauveria bassiana isolates was $97.4 \pm 2.5 \%$ for ARSEF 1480 (Brazil); $94.6 \pm 4.0$ for ARSEF 5486 
(Ivory Coast); $92.2 \pm 3.9 \%$ for the endophytic isolate CS16-1 (Colombia); and $89.7 \pm 2.5 \%$ for ARSEF 2687 (Kenya). The water used to rinse the coffee tissues after surface sterilization did not yield any fungi.

\section{Recovery of Beauveria bassiana as an endophyte}

All fungal inoculation methods were effective in introducing Beauveria bassiana into the plant, although at different levels of efficiency (Table 1). For example, seven out of 12 injected plants $(58.3 \%)$ yielded positive detection at two months, in contrast to three out of $12(25 \%)$ for the drenched plants, and one out of 12 (8.3\%) for the sprayed plants. At four months post-inoculation, $B$. bassiana was detected in only two plants out of $12(16.7 \%)$ in the injected treatment, and at six months it was only detected in one plant out of 12 in the injected treatment $(8.3 \%)$. B. bassiana was not detected in any of the treatments eight months post-inoculation. B. bassiana was not isolated from any of the control plants.

When the data are combined for all inoculation methods, the total percent of plants that tested positive for B. bassiana was $30.6 \%$ at two months, $5.5 \%$ at four months, $2.7 \%$ at six months, and $0 \%$ at eight months (Table 1 ). At two months, isolate 1480 was detected in four plants out of nine (44.4\%), isolates CS16-1 and 5486 in two out of nine plants (22.2\%), and isolate 2687 in three out of nine plants (33.3\%). At four months and six months post-inoculation, only isolate 1480 was detected in two and one plant, respectively.

B. bassiana was isolated from leaves, stems, and roots (Table 1). In the first evaluation, B. bassiana was found in the stems of eight plants, in the root of two plants, and on the leaves of one plant. At four months, B. bassiana was only isolated from two stems, and at six months from just one root. B. bassiana was not isolated from any of the tissues sampled eight months post-inoculation.

ARSEF 2687 (Kenya) was the only isolate that colonized the plant through the leaves (Table 1), while with the CS16-1 from Colombia, 1480 from Brazil and 5486 from Ivory Coast colonized through drenching. All isolates colonized the plant via injection.

Despite the addition of two replicates per each tissue and the use of selective medium, it was not possible to recover B. bassiana eight months post-inoculation. Plants that were positive for $B$. bassiana inoculation did not present any physical symptoms of damage that might otherwise indicate that the fungus was deleterious to the plant.

\section{Inoculation of coffee seeds}

Beauveria bassiana recovery in seeds that had been soaked in conidial suspensions was positive only two months post-inoculation and for only one isolate. ARSEF 5486 (Ivory Coast) was recovered from the stem of one seedling. This result indicates that $B$. bassiana rarely established endophytic associations with the host using this inoculation method.

\section{Fungal and bacterial endophytes}

Throughout all the evaluations, various fungal and bacterial endophytes were recovered from the tissues sampled. The highest number of endophytic fungi was obtained two months post-inoculation, followed by eight months post-inoculation (Table 2). The lowest number was obtained six months post-inoculation. Fungi isolated two and four months postinoculation were identified using morphological and molecular criteria and are presented in Table 3. At two months post-inoculation, 632 isolates were recovered as endophytes from which 35 species were identified, whereas at four months post-inoculation, 249 endophytic fungi were isolated and identified as belonging to 24 species. The two most frequently isolated fungal species two months post-inoculation were Penicillium citrinum and Fusarium cf. oxysporum f. sp. vasinfectum, whereas at four months post-inoculation the most abundant species recovered were Penicilium citrinum, Trichoderma sp., and Fusarium cf. oxysporum f. sp. vasinfectum. The number of endophytic fungi isolated in the first and second evaluation exhibited great variation; however, the species diversity using the Shannon index was very similar, at 2.14 and 2.42 , respectively.

The lowest incidence of endophytic fungi over all treatments was obtained from the leaves (Table 3). At two months post-inoculation, the highest incidence of endophyte recovery was in the stems followed by the roots, whereas at four months post-inoculation the highest incidence was in the roots followed by the stems (Table 3). At two months post-inoculation, only three species, B. bassiana, Fusarium sp. (2), and $P$. citrinum, occurred in leaves, stems and roots, whereas at four months post-inoculation only one species, F. cf. oxysporum f. sp. vasinfectum, was recovered from all three tissues. Stems and leaves shared only one species (Macrophomina sp.) two months post-inoculation. Stems and roots shared ten species two months post-inoculation and six species four months post-inoculation (Table 3). Leaves and roots did not share any species in both evaluations.

Altogether, the most frequently isolated species was $P$. citrinum, found in all plant tissues in the first evaluation and in the stem and roots of the second evaluation. B. bassiana showed the same pattern as P. citrinum, whereas F. cf. oxysporum f. sp. vasinfectum was present in the stem and roots of the plants of the first evaluation and in all tissues of the second evaluation. Trichoderma hamatum and Trichoderma sp. were present only in the stem and roots in both evaluations.

Bacteria were identified only as morpho-species, except for Chromobacterium sp., which was identified based on morphological comparisons with a previously identified isolate (Vega et al. 2005). The highest number of bacteria $(n=627)$ was recovered four months post-inoculation, followed by two months post-inoculation ( $n=441$; Table 2$)$. The lowest number $(n=66)$ was observed six months post-inoculation (Table 2). Seven bacterial morpho-species were found two months post-inoculation and six four months post-inoculation. Chromobacterium sp. was the second most abundant species $(20.2 \%)$ two months post-inoculation, and the third most abundant (19.5\%) four months post-inoculation.

\section{Discussion}

Beauveria bassiana has been established as an endophyte in various plants using different inoculation methods, e.g., in 
potatoes after foliar spray applications (Jones 1994); in maize plants after stem injections (Bing \& Lewis 1991, 1992a, 1992b) or after granular applications to the whorl (Lewis \& Bing 1991; Bing \& Lewis 1991, 1992a); in maize leaves after applying a $20 \mu$ conidia suspension to the abaxial side of leaves (Wagner \& Lewis 2000); in tomatoes after coating seeds with a B. bassiana conidia (Leckie 2002; Ownley et al. 2004); in opium poppies after spraying leaves or coating seeds with $B$. bassiana spore suspensions (Quesada-Moraga et al. 2006), and in cocoa (Posada \& Vega 2005) and coffee seedlings (Posada \& Vega $2006 \mathrm{~b})$ after placing spore suspensions on the radicle. Another mode of entry for B. bassiana could be through wounds caused by the coffee berry borer. This might explain our finding of $B$. bassiana as an endophyte in Colombia (Vega et al., unpubl.) in plots where there was a high level of coffee berry borer infestation as well as a high $B$. bassiana infection rate in the insects.

In contrast to the successful inoculation of leaves mentioned above, in the present study, only one of four B. bassiana isolates was recovered from sprayed coffee leaves, thus suggesting that the leaf is a poor route of entry for the fungus to colonize the coffee plant. The low recovery of $B$. bassiana from leaves could be due to specific cuticular components on the leaf and the lack of stomata on the adaxial side. It is possible that the main components on the leaf cuticle, waxes and cutin (Martin 1964), might have a detrimental effect on $B$. bassiana conidium germination. Over $70 \%$ of the total coffee leaf waxes are comprised of free primary alcohols, free acids, and alkanes (Stocker \& Wanner 1975), while more than $60 \%$ of the cutin is composed of long-chain fatty acids, such as dihydroxy-hexadecanoic acids (Holloway et al. 1972). Both the wax and cutin confer hydrophobic properties, thus making it harder for the fungal spore suspensions to adhere to the coffee leaves, which also lack hairs that could help retain the sprayed spore suspension. Cuticular waxes extracted from coffee leaves and berries have been shown to have a toxic effect on spores of Colletotrichum coffeanum, the causal agent of coffee berry disease (Steiner 1972; Lampard \& Carter 1973; Vargas 1977). However, the effects of Coffea cuticular waxes on B. bassiana conidia has not been tested. The waxy coating could also prevent infection by fungi; Heather (1967) found increased infection by Phaeoseptoria eucalypti when the waxy leaf coating in Eucalyptus bicostata leaves was removed.

The low recovery of $B$. bassiana from leaves might have also been influenced by the few natural openings in the adaxial side of the leaf, which is where the spray is deposited. Stomata in coffee are found in the abaxial side (Dedecca 1957) and are recognized in many plants as a route for infection for pathogenic bacteria and fungi (Agrios 2005), including the coffee leaf rust, Hemileia vastatrix (Silva et al. 2002; Coutinho et al. 1993). Domatia are also located in the abaxial side (Dedecca 1957; Wintgens 2004) and thus foliar sprays containing fungal suspensions are not likely to reach these natural cavities on the leaf. Another possibility for the lack of infection via the leaves could be the production of phytoalexins in response to fungal challenges (Rodrigues et al. 1975; Medeiros \& Rodrigues 1977).

The highest recovery of $B$. bassiana was from the stems of plants injected with conidia suspensions. This method of inoculation circumvents the physical barrier of the plant cuticle. A similar method has been successfully used in grasses, where fungal endophyte mycelium is inserted between the shoot and root sections (Johnson-Cicalese et al. 2000) or at the junction of the coleoptile and mesocotyl (Latch \& Christensen 1985).

Santamaría \& Bayman (2005) have reported Xylaria, Colletotrichum, Guignardia, Botryosphaeria and Pestalotia as coffee leaf endophytes in Puerto Rico. Of these, we only detected Colletotrichum in the seedlings used in our study. The reduction in B. bassiana recovery as post-inoculation time increased could be due in part to competition with other endophytes present in the coffee plant (Table 3). Even though the presence of these endophytic fungi might pose a constraint for the establishment of a specific fungal endophyte (e.g. B. bassiana), there are no published reports to support or to reject this hypothesis (but see Freeman \& Rodriguez (1993), Redman et al. (1999) and Arnold et al. (2003)). In addition to the endophytes reported in this study, we have isolated and sequenced over 170 different endophytes in coffee plants collected from the field in Hawaii, Mexico, Puerto Rico, and Colombia (Vega et al., unpubl.). A large number of fungal genera, including many of the endophytes we have found in coffee, are known to be involved in the production of metabolites active against fungi, bacteria, and insects (Vega et al., unpubl., and references therein).

It is possible that the presence of $B$. bassiana in inoculated Coffea seedlings was underestimated, as it is slow growing on the media we used as compared with the rapidly growing species Penicillium and Fusarium, which were frequently isolated as endophytes in this study. These latter fungi rapidly covered the entire surface of isolation plates, thus making it more difficult to observe and to isolate outgrowths of other fungi. The use of in planta molecular detection techniques, which we are developing for future endophyte studies, should result in a more precise estimate of $B$. bassiana establishment as an endophyte.

One important finding is that B. bassiana was isolated from plants at locations distant from the point of inoculation. Thus, B. bassiana is capable of movement within the plant. In one plant inoculated by injection in the stem with ARSEF 2687 (Kenya), the fungus was subsequently recovered from the stem and roots of the plant. Similarly, in one plant inoculated with ARSEF 5486 (Ivory Coast) via stem injection, the fungus was recovered from the roots. B. bassiana was recovered from the stem of another plant inoculated by soil drenching with ARSEF 5486 (Ivory Coast). Our attempts to visualize fungal growth in coffee tissues using various dyes have not been successful. This might be due to the selection of tissues that did not harbour B. bassiana, considering the low establishment rates we recorded in the study. In contrast, visualization of endophytes in other plants is relatively easy (Clark et al. 1983; Saha et al. 1988; Hinton \& Bacon 1985; Bacon \& White 1994; Menéndez et al. 1997; Christensen et al. 2001; Barrow \& Aaltonen 2004). Wagner \& Lewis (2000) observed B. bassiana hyphal growth in the xylem elements using light and electron microscopy; conidia were never detected in their examinations.

The results indicate that the four B. bassiana isolates used in this study have different capabilities for infection and colonization of coffee plant tissues even though there were not clear tendencies between isolates in their ability to persist as endophytes. ARSEF 1480 (Brazil) could be detected in the 
injected plants four months post-inoculation, in contrast to all the other isolates, none of which was detectable at four months. Strain suitability for endophytism is perhaps an aspect that needs to be taken into account when evaluating candidates for plant inoculation. The failure to establish endophytic infections may thus be due to innate characteristics of the isolate being used.

The low B. bassiana establishment in sprayed plants is unfortunate. Of all the inoculation methods tested, foliar sprays are the easiest to accomplish in the field. Even though stem injection resulted in highest post-inoculation recovery of B. bassiana of the three methods compared, stem inoculation might pose some difficulties in implementation unless it can be done with seedlings, although persistence of $B$. bassiana would be questionable due to other endophytes occurring in the plant. Future work will determine whether B. bassiana can be established in coffee berries after applying spore suspensions on flowers and in young coffee berries in the field.

\section{Acknowledgements}

We thank Ann Sidor and Cindy Park (USDA, ARS, Beltsville, $\mathrm{MD)}$ for excellent technical assistance in the laboratory; Richard Humber (USDA, ARS, Ithaca, NY) for providing three of the isolates used in this study. Comments by Betsy Arnold (The University of Arizona, Tucson, AZ), Meredith Blackwell (Louisiana State University, Baton Rouge, LA), Pat Dowd (USDA, ARS, Peoria, IL), Rich Humber (USDA, ARS, Ithaca, NY) and Les Lewis (USDA, ARS, Ames, IA) are greatly appreciated. The use of trade, firm, or corporation names in this publication is for the information and convenience of the reader. Such use does not constitute an official endorsement or approval by the US Department of Agriculture or the Agricultural Research Service of any product or service to the exclusion of others that may be suitable.

\section{R E F E R E N C E S}

Agrios GN, 2005. Plant Pathology, fifth edn. Elsevier Academic Press, San Diego.

Aristizabal LF, Salazar HM, Mejía CG, Bustillo AE, 2004. Introducción y evaluación de Phymastichus coffea (Hymenoptera: Eulophidae) en fincas de pequeños caficultores, a través de investigación participativa. Revista Colombiana de Entomología 30: 219-224.

Arnold AE, Mejía LC, Kyllo D, Rojas EI, Maynard Z, Robbins N, Herre EA, 2003. Fungal endophytes limit pathogen damage in a tropical tree. Proceedings of the National Academy of Sciences, USA 100: 15649-15654.

Arnold AE, Lewis LC, 2005. Ecology and evolution of fungal endophytes, and their roles against insects. In: Vega FE, Blackwell M (eds), Insect-Fungal Associations: Ecology and Evolution. Oxford University Press, New York, pp. 74-96.

Bacon CW, White jr JF, 1994. Stains, media and procedures for analyzing endophytes. In: Bacon CW, White jr JF (eds), Biotechnology of Endophytic Fungi of Grasses. CRC Press, Boca Raton, pp. 47-56.

Barrow JR, Aaltonen RE, 2004. A staining method for systemic endophyte fungi in plants. In: Lartey RT, Caesar AJ (eds),
Emerging Concepts in Plant Health Management. Research Signpost, Kerala, pp. 61-67.

Bills GF, Polishook JD, 1991. Microfungi from Carpinus caroliniana. Canadian Journal of Botany 69: 1477-1482.

Bing LA, Lewis LC, 1991. Suppression of Ostrinia nubilalis (Hübner) (Lepidoptera: Pyralidae) by endophytic Beauveria bassiana (Balsamo) Vuillemin. Environmental Entomology 20: 1207-1211.

Bing LA, Lewis LC, 1992a. Temporal relationships between Zea mays, Ostrinia nubilalis (Lep.: Pyralidae) and endophytic Beauveria bassiana. Entomophaga 37: 525-536.

Bing LA, Lewis LC, 1992b. Endophytic Beauveria bassiana (Balsamo) Vuillemin in corn: the influence of the plant growth stage and Ostrinia nubilalis (Hübner). Biocontrol Science and Technology 2: 39-47.

Bustillo AE, Cárdenas R, Villalba DA, Benavides P, Orozco J, Posada FJ, 1998. Manejo integrado de la broca del café Hypothenemus hampei (Ferrari) en Colombia. Centro Nacional de Investigaciones de Café (Cenicafé), Chinchiná, Colombia.

Carrillo E, Ochoa H, Decazy B, 1989. Evaluation of motorized knapsack spraying equipment, at low volumes, for the control of coffee fruit borer Hypothenemus hampei (Ferr.) in Guatemala. Turrialba 39: 387-392.

Chase AR, Osborne LS, Ferguson VM, 1986. Selective isolation of the entomopathogenic fungi Beauveria bassiana and Metarhizium anisopliae from an artificial potting medium. Florida Entomologist 69: 285-292.

Cherry AJ, Lomer CJ, Djegui D, Shulthess F, 1999. Pathogen incidence and their potential as microbial control agents in IPM of maize stem borers in West Africa. BioControl 44: 301-327.

Cherry AJ, Banito A, Djegui D, Lomer C, 2004. Suppression of the stem-borer Sesamia calamistis (Lepidoptera; Noctuidae) in maize following seed dressing, topical application and stem injection with African isolates of Beauveria bassiana. International Journal of Pest Management 50: 67-73.

Christensen MJ, Bennett RJ, Schmid J, 2001. Vascular bundle colonization by Neotyphodium endophytes in natural and novel associations with grasses. Mycological Research 105: 1239-1245.

Clark EM, White JF, Patterson RM, 1983. Improved histochemical techniques for the detection of Acremonium coenophialum in tall fescue and methods of in vitro culture of the fungus. Journal of Microbiological Methods 1: 149-155.

Coutinho TA, Rijkenberg FHJ, Vanasch MAJ, 1993. Development of infection structures by Hemileia vastatrix in resistant and susceptible selections of Coffea and in Phaseolus vulgaris. Canadian Journal of Botany 71: 1001-1008.

Dedecca DM, 1957. Anatomia e desenvolvimiento ontogenético de Coffea arabica L. var. typica Cramer. Bragantia 16: 315-366.

de la Rosa W, Alatorre R, Barrera JF, Toriello C, 2000. Effect of Beauveria bassiana and Metarhizium anisopliae (Deuteromycetes) upon the coffee berry borer (Coleoptera: Scolytidae) under field conditions. Journal of Economic Entomology 96: 1409-1414.

Druzhinina IS, Kopchinskly AG, Kubicek CP, 2006. The first 100 Trichoderma species characterized by molecular data. Mycoscience 47: 55-64.

Evans HC, Holmes KA, Thomas SE, 2003. Endophytes and mycoparasites associated with an indigenous forest tree, Theobroma gileri, in Ecuador and a preliminary assessment of their potential as biocontrol agents of cocoa diseases. Mycological Progress 2: 149-160.

Fowler J, Cohen L, Jarvis P, 1998. Practical Statistics for Field Biology. John Wiley \& Sons, Chichester, UK.

Freeman S, Rodriguez RJ, 1993. Genetic conversion of a fungal plant pathogen to a nonpathogenic, endophytic mutualist. Science 260: 75-78.

Ganley RJ, Newcombe G, 2005. Fungal endophytes in seeds and needles of Pinus monticola. Mycological Research 110: 318-327.

Gardes M, Bruns TD, 1993. ITS primers with enhanced specificity for basidiomycetes - application to the identification of mycorrhizae and rusts. Molecular Ecology 2: 113-118. 
Godoy MT, Pedreiro R, Queiroz CAG, Santos MSTA, Almeida SL, Corte CR, Cioni J, Mariconi FAM, 1984. Ensaio de combate a 'broca do café' Hypothenemus hampei (Ferrari, 1867) com defensivos quimicos. Solo 76: 17-22.

Goettel MS, Inglis DG, 1997. Hyphomycetes. In: Lacey LA (ed), Manual of Techniques in Insect Pathology. Academic Press, London, pp. 213-249.

Haraprasad N, Niranjana SR, Prakash HS, Shetty HS, Wahab S, 2001. Beauveria bassiana a potential mycopesticide for the efficient control of coffee berry borer, Hypothenemus hampei (Ferrari) in India. Biocontrol Science and Technology 11: 251-260.

Heather WAJ, 1967. Susceptibility of the juvenile leaves of Eucalyptus bicostata Maiden et al. to infection by Phaeoseptoria eucalypti (Hansf.) Walker. Australian Journal of Biological Sciences 20: 769-775.

Hinton DM, Bacon CW, 1985. The distribution and ultrastructure of the endophyte of toxic tall fescue. Canadian Journal of Botany 63: $36-42$.

Holloway PJ, Deas AHB, Kabaara AM, 1972. Composition of cutin from coffee leaves. Phytochemistry 11: 1443-1447.

Johnson-Cicalese J, Secks ME, Lam CK, Meyer WA, Murphy JA, Belanger FC, 2000. Cross species inoculation of chewings and strong creeping red fescues with fungal endophytes. Crop Science 40: 1485-1489.

Jones KD, 1994. Aspects of the biology and biological control of the European corn borer in North Carolina. Ph.D. thesis, Department of Entomology, North Carolina State University.

Lampard JF, Carter GA, 1973. Chemical investigations on resistance to coffee berry disease in Coffea arabica. An antifungal compound in coffee cuticular wax. Annals of Applied Biology 73: 31-37.

Latch GCM, Christensen MJ, 1985. Artificial infection of grasses with endophytes. Annals of Applied Biology 107: 17-24.

Le Pelley RH, 1968. Pests of Coffee. Longmans, London.

Leckie BM, 2002. Effects of Beauveria bassiana mycelia and metabolites incorporated into synthetic diet and fed to larval Helicoverpa zea, and detection of endophytic Beauveria bassiana in tomato plants using PCR and ITS. MSc thesis, Department of Entomology, University of Tennessee.

Lewis LC, Bing LA, 1991. Bacillus thuringiensis Berliner and Beauveria bassiana (Balsamo) Vuillemin for European corn borer control: program for immediate and season long suppression. Canadian Entomologist 123: 387-393.

Lomer CJ, Cherry A, Denis D, 1997. Systemic Beauveria isolates for control of maize stem borers in Africa. Proceedings of the 30th Annual Meeting of the Society for Invertebrate Pathology, Banff, Canada: 44.

Magurran AE, 2004. Measuring Biological Diversity. Blackwell Publishing, Oxford.

Mansingh A, 1991. Limitations of insecticides in the management of the coffee berry borer Hypothenemus hampei Ferrari. Journal of Coffee Research 21: 67-98.

Martin TJ, 1964. Role of cuticle in the defense against plant disease. Annual Review of Phytopathology 2: 81-100.

Medeiros EF, Rodrigues jr CJ, 1977. Production of phytoalexin-like substances in Coffea arabica L. leaves inoculated with several rusts not pathogenic to coffee. Proceedings of the 8th International Scientific Colloquium on Coffee, Abidjan, Ivory Coast: 511512.

Menéndez A, Delia Bertoni M, Cabral D, 1997. Endofitos fúngicos en Juncus imbricatus var chamissonis: identificación de los patrones de colonización. Revista Iberoamericana de Micología 14: 125-128.

Ownley BH, Pereira RM, Klingerman WE, Quigley NB, Leckie BM, 2004. Beauveria bassiana, a dual purpose biocontrol organism, with activity against insect pests and plant pathogens. In: Lartey RT, Caesar AJ (eds), Emerging Concepts in Plant Health Management. Research Signpost, Kerala, pp. 255-269.

Posada FJ, Villalba DA, Bustillo AE, 2004. Los insecticidas y el hongo Beauveria bassiana en el control de la broca del café. Revista Cenicafé 55: 136-149.

Posada F, Vega FE, 2005. A new method to evaluate the biocontrol potential of single spore isolates of fungal entomopathogens. Journal of Insect Science 5: 37.

Posada F, Vega FE, 2006a. Establishment of the fungal entomopathogen Beauveria bassiana (Ascomycota: Hypocreales) as an endophyte in cocoa seedlings (Theobroma cacao). Mycologia 97: 208-213.

Posada F, Vega FE, 2006b. Inoculation and colonization of coffee seedlings (Coffea arabica L.) with the fungal entomopathogen Beauveria bassiana (Ascomycota: Hypocreales). Mycoscience 47: 284-289.

Posada FJ, 1998. Production, formulation and application of Beauveria bassiana for control of Hypothenemus hampei in Colombia. Ph. D. thesis. University of London, Ascot, Berkshire.

Quesada-Moraga E, Landa BB, Muñoz-Ledesma J, JiménezDíaz RM, Santiago-Álvarez C, 2006. Endophytic colonization of opium poppy, Papaver somniferum, by an entomopathogenic Beauveria bassiana strain. Mycopathologia 161: 323-329.

Quintero HC, Bustillo AE, Benavides P, Chaves CB, 1998. Evidencias del establecimiento de Cephalonomia stephanoderis y Prorops nasuta (Hymenoptera: Bethylidae) en cafetales del departamento de Nariño, Colombia. Revista Colombiana de Entomologia 24: 141-147.

Redman RS, Freeman S, Clifton DR, Morrel J, Brown G, Rodriguez RJ, 1999. Biochemical analysis of plant protection afforded by a nonpathogenic endophytic mutant of Colletotrichum magna. Plant Physiology 119: 795-804.

Rehner SA, Buckley E, 2005. A Beauveria phylogeny inferred from nuclear ITS and EF1- $\alpha$ sequences: evidence for cryptic diversification and links to Cordyceps teleomorphs. Mycologia 97: 84-98.

Rehner SA, Posada F, Buckley E, Infante F, Castillo A, Vega FE, 2006. Phylogenetic origins of African and Neotropical Beauveria bassiana s.l. pathogens of the coffee berry borer, Hypothenemus hampei. Journal of Invertebrate Pathology 93: 11-21.

Rodrigues jr CJ, Medeiros EF, Lewis BG, 1975. Relationship between a phytoalexin-like response in coffee leaves (Coffea arabica L.) and compatibility with Hemileia vastatrix Berk. \& Br. Physiological Plant Pathology 6: 35-41.

Saha DC, Jackson MA, Johnson-Cicalese JM, 1988. A rapid staining method for detection of endophytic fungi in turf and forage grasses. Phytopathology 78: 237-239.

Santamaría J, Bayman P, 2005. Fungal epiphytes and endophytes of coffee leaves (Coffea arabica). Microbial Ecology 50: 1-8.

Silva MC, Nicole M, Guerra-Guimarães L, Rodrigues CJ, 2002. Hypersensitive cell death and post-haustorial defence responses arrest orange rust (Hemileia vastatrix) growth in resistant coffee leaves. Physiological and Molecular Plant Pathology 60: 169-183.

Steiner KG, 1972. The influence of surface wax obtained from green berries of six selections of Coffea arabica on germination of conidia of Colletotrichum coffeanum. Kenya Coffee 37: 179.

Stocker H, Wanner H, 1975. Changes in the composition of coffee leaf wax with development. Phytochemistry 14: 1919-1920.

Taylor JW, Jacobson DJ, Kroken S, Kasuga T, Geiser DM, Hibbett DS, Fisher MC, 2000. Phylogenetic species recognition and species concepts in fungi. Fungal Genetics and Biology 31: 21-32.

Vakili N.G., 1990. Biocontrol of stalk rot in corn. In: Proceedings of the Forty-fourth Annual Corn and Sorghum Industry Research Conference, 6-7 December 1989, Chicago, IL. American Seed Trade Association, Washington, DC, pp. 87-105.

Vargas E, 1977. Estudio sobre la resistencia química del café a la mancha mantecosa causada por Colletotrichum spp. 1. 
Actividad fungistática de metabolitos presentes en el tejido laminar y capa de cera de hojas. Turrialba 27: 351-354.

Vega FE, Pava-Ripoll M, Posada F, Buyer JS, 2005. Endophytic bacteria in Coffea arabica L. Journal of Basic Microbiology 45: 371-380.

Vélez P, Posada FJ, Marin MT, González E, Osorio Y, Bustillo AE, 1997. Técnicas para el control de calidad de formulaciones de hongos entomopatógenos Boletín Técnico No. 17. Cenicafé, Chinchiná, Colombia.

Villalba DA, Bustillo AE, Chaves B, 1995. Evaluación de insecticidas para el control de la broca del café en Colombia. Revista Cenicafé 46: 152-163.
Wagner BL, Lewis LC, 2000. Colonization of corn, Zea mays, by the entomopathogenic fungus Beauveria bassiana. Applied and Environmental Microbiology 66: 3468-3473.

White TJ, Bruns T, Lee S, Taylor J, 1990. Amplification and direct sequencing of fungal ribosomal RNA genes for phylogenetics In: Innis MA, Gelfand DH, Sninsky JJ, White TJ (eds), PCR Protocols: a guide to methods and applications. Academic Press, San Diego, pp. 315-322.

Wintgens JN, 2004. The coffee plant. In: Wintgens JN (ed), Coffee: Growing, Processing, Sustainable Production. Wiley-VCH, Weinheim, pp. 3-24. 